\title{
First-principles Analysis of SiC/AI Composites Interface
}

\author{
Qipeng Wang*, Junlei Shi
}

School of Materials Science and Engineering, Anhui University of Science and Technology, Huainan, China

Email address:

1625386485@qq.com (Qipeng Wang)

${ }^{*}$ Corresponding author

\section{To cite this article:}

Qipeng Wang, Junlei Shi. First-principles Analysis of SiC/Al Composites Interface. International Journal of Fluid Mechanics \& Thermal Sciences. Vol. 5, No. 4, 2019, pp. 91-95. doi: 10.11648/j.ijfmts.20190504.11

Received: August 30, 2019; Accepted: October 7, 2019; Published: October 17, 2019

\begin{abstract}
The interface of $\mathrm{SiCp} / \mathrm{Al}$ composites is an important factor affecting the properties of materials, Different interface layers have different interface bonding strengths, which have different effects on the properties of $\mathrm{SiCp} / \mathrm{Al}$ composites. In this paper, the possible binding energy of interface in SiCp/Al composites is studied, then the influence of the interfacial binding energy on the $\mathrm{SiCp} / \mathrm{Al}$ composites is analyzed, and the method of controlling the interface of $\mathrm{SiCp} / \mathrm{Al}$ composites is proposed. Firstly, three interface models that may exist in $\mathrm{SiCp} / \mathrm{Al}$ composites were constructed in Material Studio software, and the model structure was optimized, then the first-principles simulation of the optimized interfaces model of $\mathrm{SiCp} / \mathrm{Al}$ composites was carried out, and the interfacial bonding energy of $\mathrm{SiC}-\mathrm{Al}, \mathrm{SiC}-\mathrm{SiO}_{2}-\mathrm{Al}$ and $\mathrm{SiC}^{-} \mathrm{Al}_{2} \mathrm{O}_{3}-\mathrm{Al}$ was calculated respectively. The order of the interfacial binding energy was: $\mathrm{SiC}(100)-\mathrm{Al}(100)<\mathrm{SiC}(100)-\mathrm{SiO}_{2}(100)-\mathrm{Al}(100)<$ $\mathrm{SiC}(100)-\mathrm{Al}_{2} \mathrm{O}_{3}(100)-\mathrm{Al}(100)$. It can be known from the simulation results that the interfacial bonding energy of the interface layer containing the oxide is large, since the oxide can improve the wettability between the matrix and the reinforcement. Therefore, in order to obtain a well-bonded $\mathrm{SiCp} / \mathrm{Al}$ composite, the $\mathrm{SiC}$ particles are usually surface-modified to regulate the interface of the $\mathrm{SiCp} / \mathrm{Al}$ composite. Thereby, the $\mathrm{SiCp} / \mathrm{Al}$ composite material with high interface bonding strength and excellent performance is obtained.
\end{abstract}

Keywords: SiCp/Al Composite, First Principle, Interface, Simulation

\section{Introduction}

$\mathrm{SiCp} / \mathrm{Al}$ composite material is a kind of material with high specific strength, large specific modulus, good thermal conductivity, good electrical conductivity, small thermal expansion coefficient, good dimensional stability, good wear resistance [1-6] etc. It has a wide range of applications in aerospace, electronic packaging, marine, automotive, precision instruments [7-13] etc. The properties of the composite material are mainly determined by the properties of the matrix and the reinforcement and the interface formed between the two, where in the interface plays an important role in the performance of the composite. The interface properties of metal matrix composites mainly include interface bonding strength, thermal conductivity etc. The interface bonding strength is an important index to characterize the mechanical properties of the interface. It can be regarded as the critical stress acting on the interface when the metal matrix and the reinforcing phase are separated along the interface. The interface bonding strength of different interface layers is also different.

In $\mathrm{SiCp} / \mathrm{Al}$ composites, interfacial layers such as $\mathrm{SiC}-\mathrm{Al}$, $\mathrm{SiC}-\mathrm{SiO}_{2}-\mathrm{Al}, \mathrm{SiC}-\mathrm{Al}_{2} \mathrm{O}_{3}-\mathrm{Al}$ etc are usually formed. A good interfacial layer is beneficial to improve the performance of $\mathrm{SiCp} / \mathrm{Al}$ composites, so we hope to obtain good interface. The greater the interface bonding energy, the more stable the interface structure, but it is very difficult to measure the interface bonding energy by experimental methods. Therefore, researchers have widely used Materials Studio (MS) software to simulate interface bonding energy. In the $\mathrm{SiCp} / \mathrm{Al}$ composite interface simulation, the Visualizer, Castep and Forcite modules in the MS software are mainly used, and the Visualizer module can be used to build interface structure models; the Castep module can optimize the structure and the first-principles energy calculation; the Forcite module enables energy calculation, geometric optimization, dynamics simulation [14-18]. The results calculated by the first-principles method can be consistent 
with the experimental values, and this method is economical and simple. The first-principles calculation is a method based on density functional theory to determine the properties of materials such as geometry, electronic structure, thermodynamic properties and optical properties by self-consistent calculation. In the calculation, the basic physical constants that are completely independent of experience can be used to calculate the properties of the material in the ground state. It is also called the ab-initio calculation method [18].

Li [19] et al calculated the adhesion, stability, and electronic structure of the Fe/WC interface by first-principles. The adhesion work of the best $\mathrm{Fe} / \mathrm{WC}$ interface was found to be C-terminal $9.7 \mathrm{Jm}^{-2}$ and W-termination $5.1 \mathrm{Jm}^{-2}$. Luo [20] et al carried out molecular dynamics simulation of the interface of $\mathrm{Al}-\mathrm{SiC}$ formed by three kinds of low-index surfaces of $\mathrm{SiC} / \mathrm{Al}$ composites (100), (110) and (111), and calculated bonding energy and the experimental values are consistent. Donald [21] et al calculated the adhesion and stability of the $\mathrm{Al}(111) / \mathrm{WC}(0001)$ interface, and found that the most geometric structure of the $\mathrm{WC}(0001)$ surface is $\mathrm{W}$-terminally connected. Guo [22] et al simulated the Ni coating on
$\mathrm{SiCp} / \mathrm{Al}$ composites. They used the molecular dynamics simulation in MS software to calculate the interfacial binding energy between $\mathrm{Ni}$ and $\mathrm{SiCp} / \mathrm{Al}$ composites. The calculation results are consistent with the experiment.

Based on the predecessors, the interface of SiC-Al, $\mathrm{SiC}-\mathrm{SiO}_{2}-\mathrm{Al}, \mathrm{SiC}-\mathrm{Al}_{2} \mathrm{O}_{3}-\mathrm{Al}$ in $\mathrm{SiCp} / \mathrm{Al}$ composites was established by MS software, and the first-principles simulation was carried out. The bonding energy of various interface layers was calculated. The interface of the maximum bonding energy of $\mathrm{SiCp} / \mathrm{Al}$ composites can be found.

\section{Materials Studio Simulation}

\subsection{Model Construction}

In this study, the interface structure of $\mathrm{SiCp} / \mathrm{Al}$ composites such as $\mathrm{SiC}-\mathrm{Al}, \quad \mathrm{SiC}-\mathrm{SiO}_{2}-\mathrm{Al}$ and $\mathrm{SiC}-\mathrm{Al}_{2} \mathrm{O}_{3}-\mathrm{Al}$ was established by MS software. Firstly, the crystal structures of $\mathrm{SiC}, \mathrm{Al}, \mathrm{SiO}_{2}, \mathrm{Al}_{2} \mathrm{O}_{3}$ are found in the MS software material library as shown in Figure 1 (see Table 1 for the parameters of each crystal structure).

Table 1. Crystal structure parameters.

\begin{tabular}{llll}
\hline Materials & Space group & Space group code & Lattice parameter \\
\hline $\mathrm{SiC}$ & $\mathrm{P} 63 \mathrm{MC}$ & 186 & $3.078 \times 3.078 \times 10.046$ \\
$\mathrm{SiO}_{2}$ & $\mathrm{P} 6222$ & 180 & $5.01 \times 5.01 \times 5.47$ \\
$\mathrm{Al}_{2} \mathrm{O}_{3}$ & $\mathrm{R}-3 \mathrm{C}$ & 167 & $4.759 \times 4.759 \times 12.991$ \\
$\mathrm{Al}$ & $\mathrm{FM}-3 \mathrm{M}$ & 225 & $4.0495 \times 4.0495 \times 4.0495$ \\
\hline
\end{tabular}

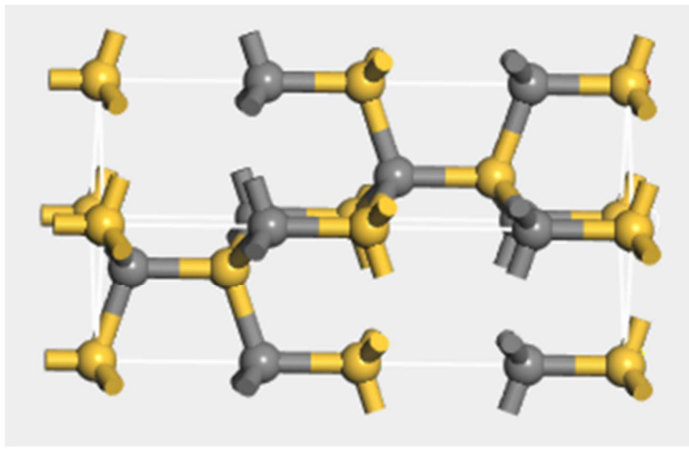

(a)

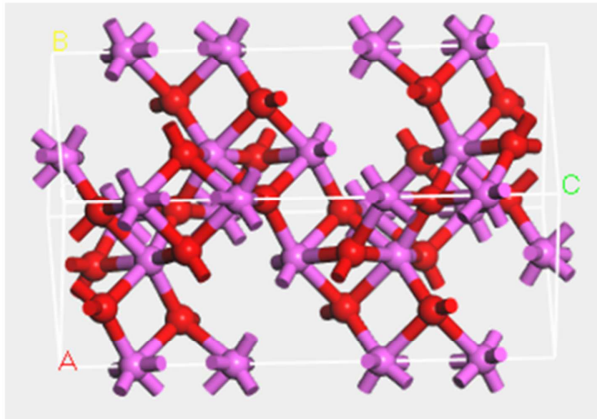

(c)

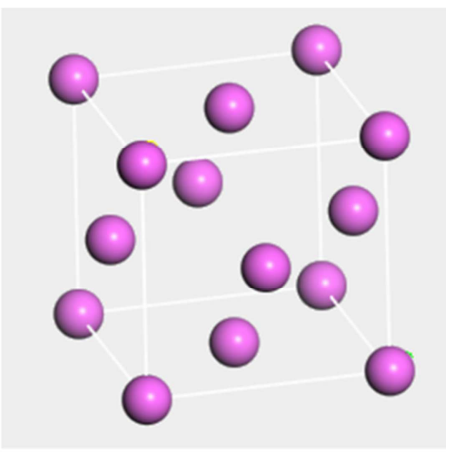

(b)

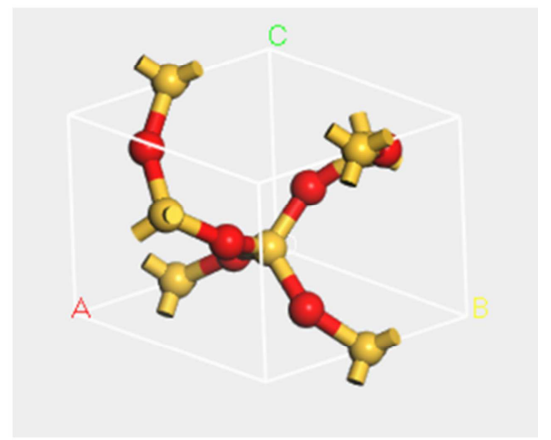

(d)

Figure 1. Different crystal structure models: (a) $\mathrm{SiC}$; (b) $\mathrm{Al}$; (c) $\mathrm{Al}_{2} \mathrm{O}_{3}$; (d) $\mathrm{SiO}_{2}$ (In the figure, the purple atom is $\mathrm{Al}$, the red atom is $\mathrm{O}$, the yellow atom is $\mathrm{Si}$, and the gray atom For C).

Then select the (100) crystal plane of each crystal structure through the Surfaces tool in the MS software, and then use the Build Layers tool to build three interface models of SiCp/Al composites, interface model shown in Figure 2. 


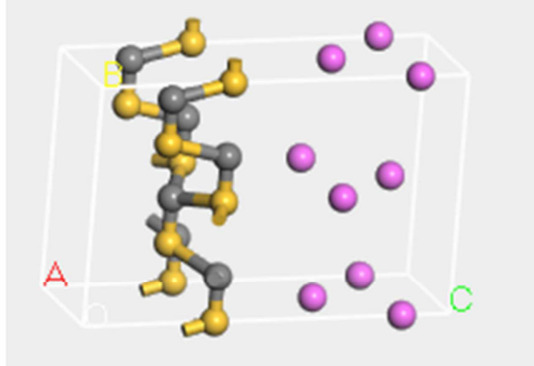

(a)

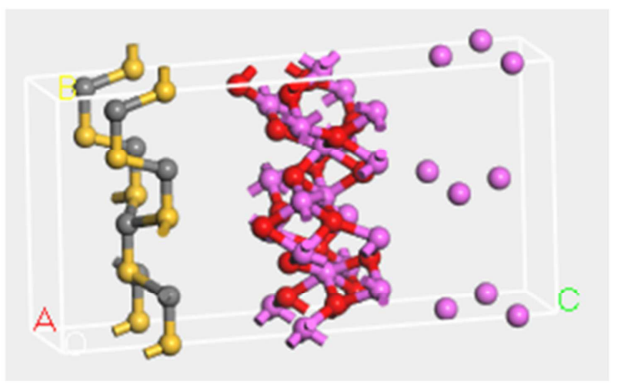

(b)

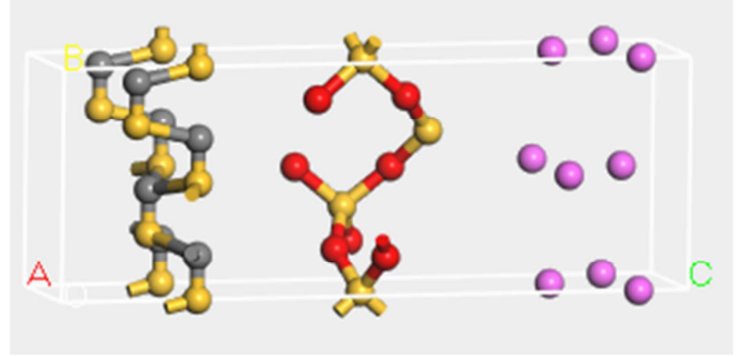

(c)

Figure 2. SiC/Al Composite Interface Model:(a) SiC-Al; (b) $\mathrm{SiC}-\mathrm{Al}_{2} \mathrm{O}_{3}-\mathrm{Al}$; (c) $\mathrm{SiC}_{-} \mathrm{SiO}_{2}-\mathrm{Al}$.

\subsection{Model Optimization and Calculation}

The structure of the established model is optimized by the Castep module in the MS software to make it closer to the real state. The optimized structure is shown in Figure 3. It can be seen from the figure that the Al atoms have different degrees of diffusion.

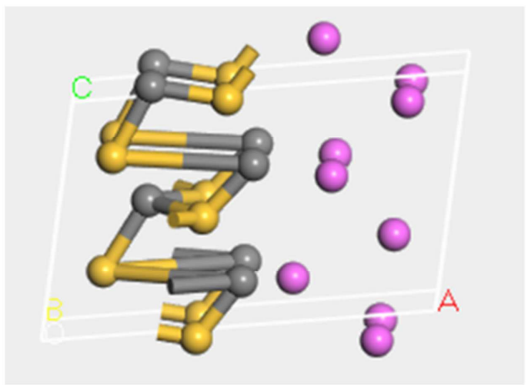

(a)

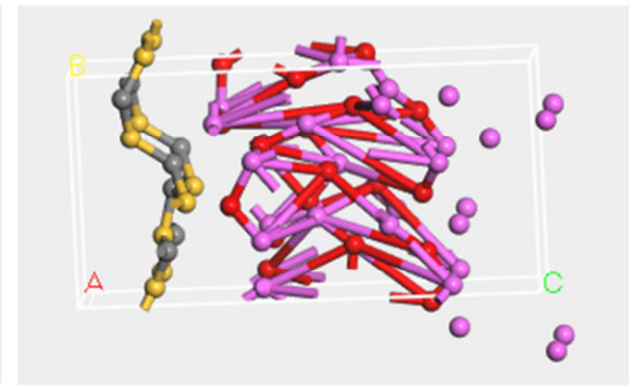

(b)

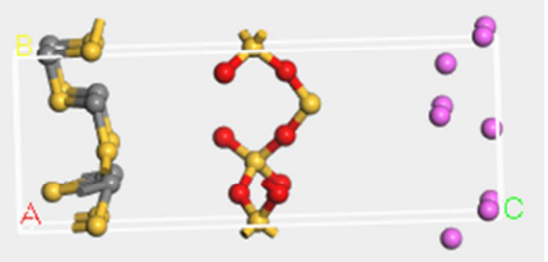

(c)

Figure 3. The optimized interface model of SiC/Al composites: (a) $\mathrm{SiC}-\mathrm{Al}$; (b) $\mathrm{SiC}-\mathrm{Al}_{2} \mathrm{O}_{3}-\mathrm{Al}$; (c) $\mathrm{SiC}_{-} \mathrm{SiO}_{2}-\mathrm{Al}$.

The optimized structure and each layer of its structure are subjected to first-principles simulation, and the total energy of each layer can be obtained to calculate the energy of the interface layer. The calculation equation is shown in (1).

$$
E_{12}=E_{1}+E_{2}-E
$$

Where $\mathrm{E}_{12}$ and $\mathrm{E}$ are the interface layer energy and the total energy, respectively. $E_{1}$ and $E_{2}$ are the energy of each layer structure. The interface bonding energy can be calculated [21] by equation (2).

$$
W=\frac{E_{12}}{A}
$$

Where $\mathrm{W}$ is the interface binding energy and $\mathrm{A}$ is the 
interface area.

\section{Results and Analysis}

In $\mathrm{SiCp} / \mathrm{Al}$ composites, the interface is a major factor affecting its performance. If a good interfacial layer is formed between the $\mathrm{SiC}$ reinforcement and the $\mathrm{Al}$ matrix, it will help to improve the performance of the $\mathrm{SiCp} / \mathrm{Al}$ composite. This requires us to research and control the interface. From the simulation results in Tables 2-4, we can see that the interfacial bonding energy of $\mathrm{SiCp} / \mathrm{Al}$ composite is: $\mathrm{SiC}-\mathrm{Al}<\mathrm{SiC}-\mathrm{SiO}_{2}-\mathrm{Al}<\mathrm{SiC}-\mathrm{Al}_{2} \mathrm{O}_{3}-\mathrm{Al}$. Since the Oxides promote good wetting bonding at the interface between $\mathrm{SiC}$ and $\mathrm{Al}$, and also avoid $\mathrm{SiC}$ and $\mathrm{Al}$ to form $\mathrm{Al}_{4} \mathrm{C}_{3}$, This brittle substance deteriorates the interface bonding strength.

Table 2. Interface Interfacial Energy of SiC-Al Composites.

\begin{tabular}{llll}
\hline Interface & Energy (ev) & Interface area $\left(\AA^{\mathbf{2}}\right)$ & Binding energy $\left(\mathbf{e v} / \AA^{\mathbf{2}}\right)$ \\
\hline $\mathrm{SiC}-\mathrm{Al}$ & -1271 & & 25.12 \\
$\mathrm{SiC}$ & -1039 & & 0.36 \\
$\mathrm{Al}$ & -223 & & \\
\hline
\end{tabular}

Table 3. Interface Interfacial Energy of $\mathrm{SiC}_{-} \mathrm{SiO}_{2}$-Al System.

\begin{tabular}{llll}
\hline Interface & Energy $(\mathbf{e v})$ & Interface area $\left(\AA^{2}\right)$ & Binding energy $\left(\mathbf{e v} / \AA^{2}\right)$ \\
\hline $\mathrm{Al}-\mathrm{SiO}_{2}-\mathrm{SiC}$ & -4222 & & \\
$\mathrm{SiC}$ & -1038 & 35.77 & 0.56 \\
$\mathrm{SiO}_{2}$ & -2944 & & \\
$\mathrm{Al}$ & -220 & & \\
\hline
\end{tabular}

Table 4. Interface Interfacial Energy of $\mathrm{SiC}-\mathrm{Al}_{2} \mathrm{O}_{3}$-Al System.

\begin{tabular}{llll}
\hline Interface & Energy (ev) & Interface area $\left(\AA^{2}\right)$ & Binding energy $\left(\mathbf{e v} / \AA^{2}\right)$ \\
\hline $\mathrm{Al}-\mathrm{Al}_{2} \mathrm{O}_{3}-\mathrm{SiC}$ & -9844 & & \\
$\mathrm{SiC}$ & -1038 & 26.39 & 0.72 \\
$\mathrm{Al}_{2} \mathrm{O}_{3}$ & -8569 & & \\
$\mathrm{Al}$ & -218 & & \\
\hline
\end{tabular}

In order to obtain a large interface binding energy, SiC particles are usually surface-modified and coated to improve wettability and prevent reaction, thereby improving interface structure stability. Surface modification of SiC particles is a common method, including coating modification and high temperature oxidation [23-25]. High temperature oxidation is the most widely used surface modification method. It is beneficial to the formation of $\mathrm{SiC}_{-} \mathrm{SiO}_{2}-\mathrm{Al}$ interface in $\mathrm{SiCp} / \mathrm{Al}$ composites and improves the performance of $\mathrm{SiCp} / \mathrm{Al}$ composites.

\section{Conclusion}

In this paper, The interface layer structure with three possible existences of $\mathrm{SiC}(100)-\mathrm{Al}_{2} \mathrm{O}_{3}(100)-\mathrm{Al}(100)$, $\mathrm{SiC}(100)-\mathrm{SiO}_{2}(100)-\mathrm{Al}(100), \quad \mathrm{SiC}(100)-\mathrm{Al}(100) \quad$ are established by MS software. Then using the Castep module to optimize the three structures and first-principles calculations, the three possible interface bonding energies are as follows:

$$
\begin{gathered}
\mathrm{SiC}(100)-\mathrm{Al}_{2} \mathrm{O}_{3}(100)-\mathrm{Al}(100)>\mathrm{SiC}(100)-\mathrm{SiO}_{2}(100)-\mathrm{Al}(100)> \\
\mathrm{SiC}(100)-\mathrm{Al}(100) .
\end{gathered}
$$

$\mathrm{SiC}-\mathrm{SiO}_{2}-\mathrm{Al}$ interface can be obtained by surface modification of $\mathrm{SiC}$ particles, which is beneficial to the formation of good interface of $\mathrm{SiCp} / \mathrm{Al}$ composites and improve the performance of $\mathrm{SiCp} / \mathrm{Al}$ composites.

\section{Acknowledgements}

This work was financially supported by Anhui Province Postdoctoral Science Foundation (2017B213).

\section{References}

[1] Zheng W, Wang Y J, Zhou M, et al. Material deformation and removal mechanism of $\mathrm{SiCp} / \mathrm{Al}$ composites in ultrasonic vibration assisted scratch test [J] Ceramics International, 2018, 44 (13): 15133-15144.

[2] Mizuuchi K, Inoue $\mathrm{K}$, Agari $\mathrm{Y}$, et al. Processing of $\mathrm{Al} / \mathrm{SiC}$ composites in continuous solid-liquid co-existent state by SPS and their thermal properties [J] Composites: Part B, 2012, 43: 2012-2019.

[3] Wang D M, Zheng $Z$ X, Lv J, et al. Enhanced thermal conductive $3 \mathrm{D}-\mathrm{SiC} / \mathrm{Al}-\mathrm{Si}-\mathrm{Mg}$ interpenetrating composites fabricated by pressureless infiltration [J] Ceramics International, 2017, 43: 1755-1761.

[4] Xiang J F, Xie L J, Gao F N, et al. Diamond tools wear in drilling of $\mathrm{SiCp} / \mathrm{Al}$ matrix composites containing Copper $[\mathrm{J}]$ Ceramics International, 2018, 44 (5) 5341-5351.

[5] Li C P, Wang Z G, Wang H Y, et al. Fabrication of Nano-SiC Particulate Reinforced Mg-8Al-1Sn Composites by Powder Metallurgy Combined with Hot Extrusion [J] Journal of Materials Engineering and Performance, 2016, 25 (11) 5049-5054. 
[6] Yang W S, Chen G Q, Wu P, et al. Electrical Discharge Machining of Al 2024-65 vol\% SiC Composites [J] Acta Metallurgica Sinica-English Letters, 2017, 30 (5) 447-455.

[7] Wei Z J, Ma P, Wang H W, et al. The thermal expansion behavior of $\mathrm{SiCp} / \mathrm{Al}-20 \mathrm{Si}$ composites solidified under high pressures [J] Materials and Design, 2015, 65: 387-394.

[8] Zhang L J, Yang D L, Qiu F, et al. Effects of reinforcement surface modification on the microstructures and tensile properties of $\mathrm{SiCp} / \mathrm{Al} 2014$ composites [J] Materials Science and Engineering A, 2015, 624: 102-109.

[9] Huang S T, Guo L, He H H, et al. Study on characteristics of $\mathrm{SiCp} / \mathrm{Al}$ composites during high-speed milling with different particle size of PCD tools [J] International Journal of Advanced Manufacturing Technology, 2018, 95: 2269-2279.

[10] Hu F, Xie L J, Xiang J F, et al. Finite element modelling study on small-hole peck drilling of SiCp/Al composites [J] The International Journal of Advanced Manufacturing Technology, 2018, 96: 3719-3728.

[11] Xiang J F, Pang S Q, Xie L J, et al. Mechanism-Based FE Simulation of Tool Wear in Diamond Drilling of $\mathrm{SiCp} / \mathrm{Al}$ Composites [J] Materials, 2018, 252 (11): 1-21.

[12] Mao X Z, Hong Y, Wang B H, et al. Fabrication, microstructures and properties of $50 \mathrm{vol} \% \mathrm{SiCp} / 6061 \mathrm{Al}$ composites via a pressureless sintering technique [J] Powder Metallurgy, 2018, 9: 1-9.

[13] Zha H T, Feng P F, Zhang J F, et al. Material removal mechanism in rotary ultrasonic machining of high-volume fraction $\mathrm{SiCp} / \mathrm{Al}$ composites [J] The International Journal of Advanced Manufacturing Technology, 2018, 97: 2099-2109.

[14] Segall M D, Lindan Philip J D, Probert M J. First-principles simulation: ideas, illustrations and the CASTEP code $[\mathrm{J}] \mathrm{J}$. Phys.: Condens. Matter 14 (2002) 2717-2744.

[15] Dongare A M, Zhigilei L V, Rajendran A M. et al. Interatomic potentials for atomic scale modeling of metal-matrix ceramic particle reinforced nanocomposites [J]. Composites Part B, 2009, 40 (6): 461-467.
[16] Dierk Raabe. Computational materials science: the simulation of materials, microstructures and properties. Weinheim: Wiley-VCH Verlag Gmb H, 1998, 47-109.

[17] Wang J S, Horsfield A, Lee Peter D, et al. Heterogeneous nucleation of solid $\mathrm{Al}$ from the melt by $\mathrm{Al}_{3} \mathrm{Ti}$ : Molecular dynamics simulations. Phys. Rev. B, 2010, 82: 144203.

[18] Milman V, Winkler B, White J A, et al. Electronic structure, properties, and phase stability of inorganic crystals: A pseudopotential plane-wave study. Int. J. Quantum Chem., 77, John Wiley \& Sons, Inc., 2000, 895-910.

[19] Li Y F, Gao Y M, Xiao B. Theoretical calculations on the adhesion, stability, electronic structure, and bonding of Fe/WC interface [J]. Applied Surface Science 257 (2011) 5671-5678.

[20] Luo X, Qian G F, Wang E G, et al. Molecular-dynamics simulation of $\mathrm{Al} / \mathrm{SiC}$ interface structures [J]. Physical Review B, 1999, 59 (15): 10125-10131.

[21] Siegel Donald J, Hector Jr Louis G, Adams James B. Adhesion, stability, and bonding at metal/metal-carbide interfaces: Al/WC [J]. Surface Science 498 (2002) 321-336.

[22] Guo S W, Li L B, Zhang G Y, et al. Adhesion Analysis of Electroless Ni Coating on SiCp/Al Composite Mirror Substrate [J]. Rare Metal Materials and Engineering, 2008, 37 (6): 0960-0963.

[23] Subhash Singh, Kaushik Pal. Effect of surface modified silicon carbide particles with $\mathrm{Al}_{2} \mathrm{O}_{3}$ and nanocrystalline spinel $\mathrm{ZnAl}_{2} \mathrm{O}_{4}$ on mechanical and damping properties of the composite [J]. Materials Science \& Engineering A. 2015, 644: 325-336.

[24] Hu M, Zhang Y L, Tang L L, et al. Surface modifying of SiC particles and performance analysis of $\mathrm{SiCp} / \mathrm{Cu}$ composites $[\mathrm{J}]$. Applied SurfaceScience. 2015, 332: 720-725.

[25] Ortega-Celaya F, Pech-Canul M I, López-Cuevas J. Microstructure and impact behavior of $\mathrm{Al} / \mathrm{Si} \mathrm{Cp}$ composites fabricated by pressureless infiltration with different types of SiCp. Materials [J]. Processing Technology, 2007. 183: 368-373. 